Parkinson Hastalığında D Vitamininin Etkisi: Güncel Yaklaşımlar

\author{
Nur Bengü Erdem ${ }^{1}$, Aylin Ayaz ${ }^{1}$ \\ ${ }^{1}$ Hacettepe Üniversitesi Să̆llk Bilimleri Fakültesi, Beslenme ve Diyetetik Bölümü
}

\begin{abstract}
Özet
D vitamininin kalsiyum dengesi ve kemik sağlığını düzenleme dışında otokrin ve parankrin özellikleri ile hormon özelliği taşıdığı düşünülmektedir. Son yıllarda D vitamininin çeşitli fizyolojik görevleri tanımlanmıştır. D vitamini eksikliğinin kanser, kardiyovasküler hastalıklar, diyabet, felç ve nörodejeneratif hastalıklar gibi çok sayıda kronik hastalıkla ilişkili olduğu bulunmuştur. D vitamini reseptörü (VDR) ve vitaminin aktivasyonundan sorumlu 1- $\alpha$ hidroksilaz enziminin beynin çeşitli bölgelerinde bulunması periferal ve merkezi sinir sisteminin normal fonksiyonlarını sürdürmesinde gerekli olduğu ve bilişsel sağlıkta önemli rol alabileceğine işaret etmektedir. Parkinson en yaygın görülen nörodejeneratif hastalıklardan biridir. Hastalığın patogenezinde çevresel ve genetik etmenlerin rol aldığı belirtilmektedir. Çevresel faktörler içerisinde D vitamini gibi bazı vitaminlerin hastalığın gelişmesiyle ilgili olabileceği düşünülmektedir. Yapılan çalışmalara göre Parkinsonlu bireylerde düşük $\mathrm{D}$ vitamini düzeylerinin hastalığın oluşumunda ve ilerlemesinde rol oynayabileceği öne sürülmektedir. Bu derleme yazıda Parkinson hastalığında D vitaminin etkisini güncel çalışma sonuçlarına göre değerlendirmek amaçlanmıştır.
\end{abstract}

Anahtar kelimler: D vitamini, Parkinson hastalığı, VDR, yetersizlik, nörodejeneratif

Sorumlu Yazar: Nur Bengü Erdem, Hacettepe Üniversitesi, Sağlık Bilimleri Fakültesi, Beslenme ve Diyetetik Bölümü. Hacettepe Üniversitesi, Sağlık Bilimleri Fakültesi, Beslenme ve Diyetetik Bölümü, Sıhhiye, Ankara. Telefon: 0(312) 30510 94, E-posta: bengu.erdem@hacettepe.edu.tr

Gönderim Tarihi: 27 Mart, 2018

Kabul Tarihi: 31 Ağustos, 2018 
Review

Parkinson Disease and Vitamin D

\title{
Effect of Vitamin D in Parkinson's Disease: Current Approaches
}

\author{
Nur Bengü Erdem ${ }^{1}$, Aylin Ayaz ${ }^{1}$ \\ ${ }^{1}$ Hacettepe University, Faculty of Healh Sciences,Department of Nutrition and Dietetics
}

\begin{abstract}
Beyond its calcium and bone health regulation; vitamin $\mathrm{D}$ is considered hormone thanks to autocrine and paracrine properties. In recent years, various physiological functions of vitamin D have been defined. It has been detected that vitamin D deficiency is associated with numerous diseases such as; cancer, diabetes mellitus, stroke, cardiovascular and neurodegenerative. That Vitamin D receptor (VDR) and 1 $\alpha$-hydroxylase enzyme activating vitamin D are located in different areas of brain indicate that vitamin is linked with cognitive health and maintaining normal functions of peripheral and central nervous system. Parkinson is one of the most common neurodegenerative disease. It has been displayed that environmental and genetic factors are related at pathogenesis of disease. Environmental factors like vitamin D is thought about development of disease. According to studies it has been suggested that low vitamin D levels may play role progression and development of disease. The aim of this study is to assess of vitamin D in Parkinson's Disease by current studies results.
\end{abstract}

Keywords: Vitamin D, Parkinson's disease, VDR, insufficiency, neurodegenerative

Corresponding Author: Nur Bengü Erdem,Hacettepe University, Faculty of Health Sciences, Department of Nutrition and Dietetics, Sihhiye, Ankara. Phone: 0 (312) 30510 94, E mail: bengu.erdem@ hacettepe.edu.tr

Submission Date: $27^{\text {th }}$ of March, 2018

Acceptance Date: $31^{\text {st }}$ of August, 2018 


\section{Giriș}

D vitamininin endokrin sistem, kalsiyum homeostazı ve kemik sağlığında kritik rol oynadığı bilinmektedir. Ancak son yıllarda D vitamininin kemik ve mineral sağlı̆̆ dışında.hücre farklılaşması ve gelişimi ile immünomodülasyon üzerine etkileri ile beyin gelişimi ve fonksiyonunda da rolü olması gibi vücutta çok sayıda fizyolojik görevleri tanımlanmıştır (Buell ve Dawson-Hughes, 2008; Peterson, 2014). D vitamini eksikliğinin kanser, kardiyovasküler hastalıklar, diyabet, felç ve nörodejeneratif hastalıklar gibi çok sayıda kronik hastalıkla ilişkili olduğu bulunmuştur (Buell ve Dawson-Hughes, 2008). Parkinson çok yaygın görülen nörodejeneratif hastalıktır ( $\mathrm{Lv}$ ve diğ. 2014). D vitamininin dopamin biyosentezinde tirozin hidroksilaz gen ekspresyonunu düzenlemesindeki rolü Parkinson patogenezi ile ilişkili olduğunu göstermektedir (Garcion, Wion-Barbot, Montero-Menei, Berger, ve Wion, 2002; Puchacz, Stumpf, Stachowiak, ve Stachowiak, 1996). D vitaminin aktif formuna dönüşümünü sağlayan $1 \alpha$-hidroksilaz enzimi ile D vitamini reseptörleri'nin (VDR) beyinde substantia nigra bölgesinde bulunduğu ve hastalık nedeniyle bu bölgenin etkilendiği bilinmektedir. (Garcion ve diğ., 2002; Puchacz ve diğ., 1996) Uzun süre yetersiz D vitamini alımının dopaminerjik nöronların kronik kaybına neden olduğu ve parkinsonun patogenezinde önemli rol oynadığı öne sürülmektedir. (Ozturk ve diğg., 2016). Hastalık genetik yatkınlığın çevresel etmenler ile etkileşimi sonucunda oluşmaktadır. Beslenme modeli önemli bir çevresel etmendir. Sağlıklı beslenme modeli çok sayıda hastalığın oluşumunu önlerken bu durumun Parkinsonda geçerli olup olmadığı tartışma konusudur (Erro ve diğ., 2017). Son dönemdeki artan kanıtlarda Parkinsonlu bireylerin 25-OH D vitamini düzeyinin sağlıklı bireylere göre daha düşük olduğunu ve D vitamini eksikliğinin Parkinson hastalığı ile bağlantılı mekanizmalarda ilişkili olabileceği öne sürülmektedir.(Lv ve diğ., 2014) Bu derleme yazıda Parkinson hastalığında D vitaminin etkisini güncel çalışma sonuçlarına göre değerlendirmek amaçlanmıştır

\section{Parkinson Hastalı̆̆ı}

Parkinson, dopaminerjik nöronların dejenerasyonu ve disfonksiyonu ile karakterizedir (Shen ve Ji, 2015). Beyindeki dopamin sentezleyen hücrelerin azalması ile beyindeki dopamin miktarı azalır (Combs ve Cox, 2017). Alzheimer'dan sonra en sık görülen nörodejeneratif hastalık olarak tanımlanmıştır (Ozturk ve diğ., 2016). Parkinson ağırlıklı olarak yaşlı nüfusu etkilemektedir. Yapılan bir meta analizin sonuçlarına göre ilerleyen yaşla birlikte Parkinson prevelansında artış olduğu belirlenmiştir (Pringsheim, Jette, Frolkis ve Steeves, 2014). Hastalık genel olarak 55-65 yaş aralığında gelişirken, 60 yaş üstü bireylerin \%1-2'sinde 
görülmektedir. $\mathrm{Bu}$ değer 85-89 yaş aralığında \%3.5'e kadar yükselmektedir. Genel popülasyonun \%0.3’ünde görülürken, erkeklerde görülme sıklı̆̆ı kadınlara kıyasla 1.5 kat daha yüksektir (Rizek, Niraj Kumar MD ve Jog, 2016). Hastalık motor ve motor olmayan semptomları içermektedir (Rizek ve diğ., 2016). Dinlenme anında tremor, katılık, yavaşlık ve postürel duruştaki sabitliği sağlayamama bazı majör semptomlardır. Konstipasyon, uyku bozukluğu ve göz problemleri erken dönemde gözlenen motor dışı semptomlardır. Motor semptomların bazal gangliadaki dopamin hücrelerinin kaybından dolayı olduğu düşünülmektedir (Peterson, 2014). Patolojik muayene sirasında motor semptomlar gözlenmeye başlandığında substantia nigra bölgesindeki hücrelerin \%30-70'inde hücre kaybı olduğu kanıtlanmıştır. Tedavinin temel noktası dopaminerjik ilaçlarla dopamini yerine koymadır. Levodopa tedavisi Parkinson hastalığındaki motor semptomlar için altın standart olarak kabul edilmektedir (Ellis ve Fell, 2017; Rizek ve diğ., 2016). Tedavinin temelinde hastanın yaşam kalitesini sürdürmek ve semptomlarını azaltmak esastır. Hastalığa yönelik bilgiler sınırlı olup önlemeye yönelik bilgi bulunmamaktadır (Combs ve Cox, 2017).

\section{Vitamini ve Serum Düzeyi}

D vitamini yağda çözünür hormon benzeri etkileri olup sağlıklı yaşamın sürdürülmesinde elzemdir (Shen ve Ji, 2015). Günlük D vitamini gereksinmesi diyetle alım ve deri yoluyla sentezlenmek üzere iki ana kaynaktan karşılanmaktadır (Peterson, 2014). Deri yoluyla sentezlenen $\mathrm{D}_{3}$ formu $\mathrm{D}$ vitamininin esas kaynağını oluşturmaktadır. Günlük gereksinmenin \%20'si yumurta, balık, karaciğer, zenginleştirilme yapılan süt ürünleri gibi besinlerden karşılanırken, \%80’i deri yoluyla sentezlenmektedir (J. Wang, Yang, Yu, Shao, ve Wang, 2016). D vitamini ilk olarak deride 7-dehidrokolesterolden ultraviyole B 1şığının etkisiyle sentezlenmektedir. Karaciğerde 25-hidroksilaz enzimi ile $25(\mathrm{OH}) \mathrm{D}_{3}$ vitamini oluşmakta daha sonra ise böbreklerde $1 \alpha$-hidoksilaz enzimi ile hidroksilasyonu sonucu vitaminin aktif formu olan $1,25(\mathrm{OH})_{2} \mathrm{D}_{3}$ sentezlenmektedir (de Jongh, van Schoor, ve Lips, 2017; Garcion ve diğg., 2002). D vitamini ayrıca besinlerden ve besin desteklerinden $\mathrm{D}_{2}$ ve $\mathrm{D}_{3}$ formuyla alınmaktadır (Shen ve Ji, 2015). Serum $25(\mathrm{OH}) \mathrm{D}_{3}$ vücuttaki D vitamini seviyesini belirlemede kullanılan biyokimyasal göstergedir. Serum $25(\mathrm{OH}) \mathrm{D}_{3}$ düzeyinin $<20 \mathrm{ng} / \mathrm{ml}$ (50nmol/L) olmas1 eksiklik, $20-30 \mathrm{ng} / \mathrm{ml}(50-75 \mathrm{nmol} / \mathrm{L})$ yetersizlik, $30 \mathrm{ng} / \mathrm{ml}(75 \mathrm{nmol} / \mathrm{L})$ ise yeterli düzey olarak tanımlanmıştır. (Garcion ve diğ., 2002; J. Wang ve diğ., 2016). Bu referans değerler mevsimlere göre değişmektedir. D vitamini eksikliği tüm yaş gruplarını etkileyen durum olup yaşam tarzı ve çevresel etmenlerle ilişkili olduğu bildirilmiştir. 
Vitaminin eksikliğine duyarlı spesifik risk grupları; çocuklar, gebeler, özellikle bakım evlerinde yaşayan yaşı ıireyler ve eve bağımlı bireylerdir. (de Jongh ve diğ., 2017).

\section{VDR Polimorfizminin Parkinson Üzerine Etkileri}

Çok sayıda genetik risk faktörü ile gen-çevre arasındaki etkileşimlerin Parkinson hastalığının gelişiminde etkili olduğu bildirilmiştir (Kang ve diğ., 2016). D vitamininin $1,25(\mathrm{OH})_{2} \mathrm{D}_{3}$ 'e dönüşümünde görev alan $1 \alpha$-hidroksilaz ve VDR beyinde hipotalamus ve substantia nigra bölgesindeki muhtemelen dopaminerjik nöronlardan salgılanmaktadır.1,25 $(\mathrm{OH})_{2} \mathrm{D}_{3}$ 'ün fonksiyonları VDR aracılığıyla düzenlenmektedir. VDR ve $1 \alpha$-hidroksilazın beyindeki salınımı Parkinson etiyolojisinde D vitamininin önemli rolü olduğu düşüncesini desteklemektedir. VDR polimorfizmlerinin çok sayıda nörodejeneratif hastalığın gelişiminde etkisinin olduğu ileri sürülmektedir. (Butler ve diğ., 2011; Eyles, Smith, Kinobe, Hewison, ve McGrath 2005). VDR gen transkripsiyonunu inceleyen ve araştıran hayvan çalışmalarında D vitamini ve VDR'nin beyin gelişiminde ve sinir büyüme faktör sentezinin uyarılmasında kilit rol oynadığı gösterilmiştir (Han, Xue, Li, Chen ve Xie, 2012). D vitamininin biyolojik aktivasyonlarının düzenleyicisi olan VDR'de gerçekleşen polimorfizmler ve Parkinson hastalığı riski arasında bir ilişki olduğu belirlenmiştir (Butler ve diğ., 2011; Török ve diğ., 2013). . (L. Wang ve diğ., 2015). Sağlıklı ve Parkinsonlu bireylerin VDR reseptöründe genetik varyasyonların olabileceği bildirilmiştir (Rimmelzwaan, van Schoor, Lips, Berendse ve Eekhoff, 2016). Yapılan iki çalışmada, rs10735810 (FokI) C alleleri ile Parkinson hastalığı arasında anlamlı bir ilişki bulunmuş ve kontrol grubuna kıyasla $\mathrm{C}$ allellerinin parkinsonlu bireylerde daha sık görüldüğü tespit edilmiştir. (Han ve diğ., 2012; Török ve diğ., 2013). Gen polimorfizmlerinin saptanması, optimal serum D vitamini düzeylerinin sürdürülebilmesi için hangi bireylerin suplemantasyondan daha fazla yararlanabileceğini belirlemek açısından önemlidir. (L. Wang ve diğ., 2015) Macarlarda yapılan bir çalışmada, Parkinsonlu bireylerde FokI C alleli ve Parkinson hastalığı arasında ilişki olduğu ve C allelinin sıklığının kontrol grubuna göre daha yüksek olup bu polimorfizmin Parkinson gelişiminde rolü olabileceği bildirilmiştir. (Török ve diğ., 2013). Kore'de gerçekleştirilen bir çalışmada, 146 Parkinsonlu ve 154 sağlıklı bireyde, VDR gen polimorfizmi ve Parkinson hastalığı arasındaki ilişki araştırılmıştır. Çalışmanın sonuçlarına göre BsmI, FokI, ApaI ve TaqI genotipleri ile Parkinson hastalığı arasında bir ilişki bulunmamıştır. Serum 25(OH) $\mathrm{D}_{3}$ seviyeleri düzenlendikten sonra VDR genetik varyansları incelendiğinde TaqI ve BsmI minör allellerinin Parkinson riskini arttırdığı bulunmuştur. Ancak bu sonuçlar gen-çevre etkileşimi olabileceğinden dikkatli yorumlanmalıdır (Kang ve diğ., 2016). VDR gen polimorfizmleri ve 
Parkinson hastalığına yatkınlığı araştıran bir meta analiz çalışmasının sonuçlarına göre ApaI, BsmI ve TaqI polimorfizmleri ile Parkinson hastalığına duyarlılık arasında bir ilişki bulunmamıştır (Zhang, He, Ma, Li ve Lu, 2014). Yapılan çalışmalarda farklı etnik kökenlere sahip bireylerin seçilmesi, incelenen bireylerin yaş grubunun farklı olması, D vitaminleri düzeyine bakılan dönemlerin farklı olması, örneklem büyüklügüünün az olması, VDR polimorfizmleri ve Parkinson arasındaki ilişkinin saptanmasında kesin bir yargıya varılmasını engellemektedir.

\section{Vitamininin Antioksidan Özelliğinin Parkinson Üzerine Etkileri}

Oksidatif stres, Parkinson hastalı̆̆ının oluşumuna neden olurken D vitamini seviyesinin düşük olması da antioksidan kapasitenin azalmasına ve hastalık riskinde artışa neden olduğu bildirilmiştir (Henchcliffe ve Beal, 2008). 1,25 (OH $)_{2}$ D3 vitamini, serbest radikal olup hücrelere zarar veren nitrik okside katalize olan uyarılabilir nitrik oksidaz (İnos) sentezini inhibe etmektedir (Garcion, Nataf, Berod, Darcy ve Brachet, 1997; Garcion ve diğ., 1998). Ayrıca $1,25(\mathrm{OH})_{2} \mathrm{D}_{3}$ vitamini glutatyon sentezinde önemli olan $\gamma$-glutamil transpeptidaz aktivitesini uyarmaktadır. . Glutatyon bir antioksidan olup serbest radikalleri nötralize ederek hücre hasarını önlemektedir (Dringen, Gutterer ve Hirrlinger, 2000; Garcion, Sindji, Leblondel, Brachet ve Darcy, 1999). Glutatyonun merkezi sistem hücreleri üzerinde geniş kapsamda koruyucu etkisi bulunmaktadır. Normal koşullarda glutatyon nöronlarda fazla miktarda bulunmakta ve hidrojen peroksite karşı nöron koruyucu özelliği bulunmaktadır. $\gamma$ glutamil transpeptidaz beyindeki glutatyon döngüsünde etkili olduğu için 1,25 $(\mathrm{OH})_{2} \mathrm{D}_{3}$ 'ün beyin detoksifikasyon sürecini kontrol edebildiği ileri sürülmektedir (Shinpo, Kikuchi, Sasaki, Moriwaka ve Tashiro, 2000).

\section{Parkinsonlu Bireylerde D Vitamininin Kemik Mineral Yoğunluğu Üzerine Etkisi}

D vitamini eksikliği Parkinsonlu bireylerde kemik mineral yoğunluğunun daha düşük olmasının başlıca nedenlerinden biridir. Güneş ışığına çıkma durumlarının kıyaslandığında bir çalışmada Parkinson hastalığının başlangıcındaki bireylerde günlük $15 \mathrm{dk}$ dan daha az güneşlenenlerin oranı \%74 kontrol grubunda ise \%19 olarak ve Parkinsonlu bireylerin \%59'unun diyetle günde 200 IU'den daha az D vitamini aldığı belirlenirken, kontrol grubunda ise bu oran \%4 olarak bulunmuştur. (Abou-Raya, Helmii ve Abou-Raya, 2009). Elli yaş ve üzeri 120 'den fazla parkinsonlu kadın bireyde yapılan bir çalışmada, 5 yıl süresince postür ve kırık oranı takip edilmiştir ve çalışma sonuçlarına göre bireylerin daha düşük D vitamini aldığı ve daha fazla omurga kırığı yaşadığı bildirilmiştir. Ayrıca kemik mineral yoğunluğu 
postürü kamburlaşan grupta daha hızlı azalmıştır (Sato, Iwamoto ve Honda, 2011). Dışarıda geçirilen zaman ve güneş 1şığından faydalanma durumu ile Parkinson hastalığı arasındaki ilişkinin incelendiği bir çalışmada, dışarıdaki aktivitelerde çalışan erkeklerin Parkinson hastalığı geçirme riskinin daha düşük olduğu saptanmıştır (Kenborg ve diğ., 2010). Parkinsonlu bireylerin yetersiz beslenme, düşük vücut ağırlığı ve azalan kas dayanıklılığı ve buna paralel olarak düşük kemik mineral yoğunluğuna ilgili çok sayıda neden bulunmaktadır. Aynı zamanda Parkinson hastalığından kaynaklı hareket kabiliyetindeki azalma daha düşük serum D vitamini seviyelerine ve sonuç olarak hızlı kemik kaybına neden olabilir.(Peterson, 2014). Parkinsonlu bireylerde düşük kemik mineral yoğunluğunun bir nedeni de L-dopa tedavisinden kaynaklanan hiperhomosisteinemi olduğu düşünülmektedir. Homosistein, osteoklastların farklılaşmasını ve osteoblastların apoptozunu uyarmaktadır (Erro ve diğ., 2017; Herrmann ve diğ., 2005). Parkinsonlu bireylerde sık karşılaşılan bir sorun olan malnütrisyon, D vitamini stabilitesini olumsuz yönde etkilerken, bu durum folik asit ile $\mathrm{B}_{12}$ yetersizliğiyle sonuçlanmakta ve homosisteinin artışına neden olmaktadır. Homosistein katabolizması; folik asit B12, B6 vitaminine bağlı olup; buna bağlı olarak B12 ve folik asit eksikliği hiperhomosisteinemiye neden olabilir. (Peterson, 2014) Malnütrisyon sonucu beden kütle indeksindeki düşüş, kemik mineral yoğunluğunda azalmaya neden olan etmenlerden biri olarak gösterilmektedir. (Ozturk ve diğ., 2016). Çin'de gerçekleştirilen bir çalışmada Parkinson hastalığının başlangıç aşamasında olan 209 kişi ve 210 sağlıklı bireyin dışarıda geçirilen süre ile diyetle D vitamini alımları arasındaki ilişki araştırılmış ve çalışma sonuçlarına göre dışarıda geçirilen süre ile D vitamini alımları arasında ters ilişki bulunurken bu ilişki istatistiksel olarak anlamlı bulunmuştur. (Zhu ve diğ., 2014). Yapılan çalışmalarda parkinsonlu bireylerde kemik mineral yoğunluğu skorlarının ve D vitamini seviyelerinin daha düşük olması açısından kırık riskine dikkat edilmeli ve önleyici tedbirler alınmalıdır.

\section{Parkinsonlu Bireylerde D Vitamini Alımına Yönelik Çalışmalar}

Yeni tanı almış parkinsonlu bireylerde ve kontrol grubunda besin tüketim sıklığı ve soruşturma yöntemi ile diyetle D vitamini alım düzeylerinin belirlendiği bir çalışmada toplam D vitamini alımı ile Parkinson hastalığı arasında negatif ilişki saptanmıştır. (Zhu ve diğ., 2014). Parkinsonlu bireylerde D vitamini desteğinin yapıldığı çift- kör plasebo kontrollü çalışmada 12 ay boyunca 56 parkinsonlu birey $1200 \mathrm{IU} /$ gün D vitamini alırken, 58 birey ise plasebo almıştır. FokI TT aleline sahip bireyler D vitamini desteğine tam yanıt verirken, VDR FokI CT'li bireylerin orta düzeyde yanıt verdiği saptanmıştır. Ancak FokI CC li bireyler D vitamini desteğine plasebo grubuna kıyasla anlamlı bir etki göstermemiştir (Suzuki ve diğ., 
2013). Çin'de gerçekleştirilen bir çalışmada diyetle D vitamini alım miktarlarının yeni tanı almış parkinsonlu bireylerin $(8.3 \pm 3.7 \mathrm{~g} /$ gün $)$ kontrol grubuna $(9.0 \pm 4.6 \mathrm{~g} /$ gün$)$ kıyasla anlamlı ölçüde düşük olduğu (p<0.01) tespit edilmiştir. (J. Wang ve diğ., 2016). Yapılan bir başka çalışmada ise D vitamini alım düzeyleri yeni tanı alan parkinsonlu bireyler $(10.9 \pm 6,4 \mu \mathrm{g})$ ve kontrol grubu $(10.0 \pm 5.7 \mu \mathrm{g} / \mathrm{g})$ için karşılaştırılmıştır. Çalışma sonucuna göre D vitamini alımı ve Parkinson hastalığı arasında ilişki bulunmamıştır (Miyake ve diğg., 2011). Ratlar üzerinde D vitamini desteğinin etkisinin incelendiği bir çalışmada substantia nigradaki oksidatif hasarın azaldığ 1 bildirilmiştir (Lin, Fan, Yang, Hsu ve Yang, 2003). Ratlarda yapılan diğer bir çalışmada ise zarar görmüş dopaminerjik nöronların düşük dozlarda $1,25(\mathrm{OH})_{2} \mathrm{D}_{3}$ desteğinin toksisiteye karşı koruduğu, yüksek dozlarının ise toksik etkiyi arttırdığı saptanmıştır (Shinpo ve diğ., 2000). Bir başka çalışmada ise böbreklerdeki anormal D vitamini metabolizmasından kaynaklı yüksek $1,25(\mathrm{OH})_{2} \mathrm{D}_{3}$ düzeylerinin nörotoksisiteyi arttırdığg gözlenmiştir (Kosakai ve di $\breve{g} ., 2011)$.

\section{Parkinsonlu Bireylerde D Vitamini Düzeyini Saptamaya Yönelik Çalışmalar}

Düşük D vitamini düzeylerinin Parkinson patogenezi ve gelişiminde önemli rol oynadığı bildirilmiştir (Shen ve Ji, 2015). İlk olarak 1997 yılında Sato ve arkadaşları tarafından yapılan bir çalışmada parkinsonlu bireylerin kontrol grubuna kıyasla D vitamini düzeylerinin daha düşük olduğu gösterilmiştir (Sato, Kikuyama ve Oizumi, 1997). D vitamini düzeylerinin Parkinsonlu, Alzheimerlı ve kontrol grubundaki bireylerden arasında kıyaslandığı bir çalışmada (1992-2007 yılları arasında); D vitamini yetersizliği Parkinsonlu bireylerde \%55 ile, Alzheimerlı bireylerden (\%41) ve kontrol grubundan (\%36) daha yüksek düzeyde olduğu bulunmuştur (Evatt ve diğ., 2008). Yapılan bir çalışmada serum $25(\mathrm{OH}) \mathrm{D}_{3}$ vitamini, $25(\mathrm{OH}) \mathrm{D}_{2}$ ve $25(\mathrm{OH}) \mathrm{D}_{3}$ düzeyleri ile Parkinson hastalığı arasında negatif ilişki saptanmıştır (L. Wang ve diğ., 2015). Türkiye'de yapılan bir çalışmada, kontrol grubuna kıyasla; Parkinsonlu bireylerde düşük D vitamini seviyeleri ve yüksek düzeydeki D vitamini yetersizliği oranı osteoporoz gelişimindeki ağırlıklı faktörler olarak bulunurken; parkinsonlu kadınlarda kontrol grubuna kıyasla lumbar omurga ve kalçadaki osteopeni oranı daha yüksek olup bu durum istatistiksel açıdan anlamlı bulunmuştur. (Ozturk ve diğ., 2016). D vitamini ve Parkinson hastalığı arasındaki ilişkinin 14 gözlemsel, 1 müdahale ve 5 fare çalışmasının değerlendirildiği sistematik derlemede parkinsonlu bireylerde $25(\mathrm{OH}) \mathrm{D}_{3}$ vitamininin seviyelerinin daha düşük olduğu belirlenmiştir (Rimmelzwaan ve diğ., 2016). Yapılan bir meta analizi çalışmasında 1008 parkinsonlu birey ve 4536 kişiden oluşan kontrol grubunun D vitamini düzeyi incelenmiştir. $\mathrm{Bu}$ çalışmaya göre $\mathrm{D}$ vitamini yetersizliği olan 

$\left(25(\mathrm{OH}) \mathrm{D}_{3}<(75 \mathrm{nmol} / \mathrm{L})\right.$ bireylerde Parkinson hastalık riskinin arttığı ve vitaminin eksikliği durumunda ise $(25(\mathrm{OH}) \mathrm{D} 3<50 \mathrm{nmol} / \mathrm{L})$ riskin iki kat arttığı gözlenmiştir. (Lv ve diğ., 2014). D vitamini eksikliği ve nörodejeneratif hastalıkların prevalansı yaşlı bireylerde daha

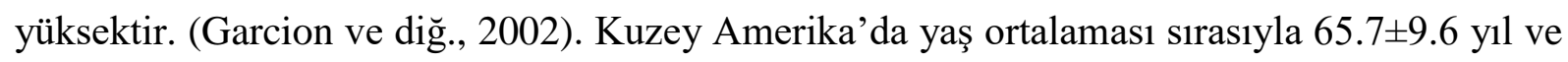
$68 \pm 10.4$ yıl olan 388 Parkinsonlu ve 283 sağlıklı bireyde D vitamini düzeyleri incelenmiş ve Parkinsonlu bireylerin \%17.6'sında kontrol grubunun ise \%9.3'ünde D vitamini eksikliği saptanmıştır (Ding ve diğ., 2013). Altmış beş yaş ve üzeri bireylerde gerçekleştirilen bir çalışmada 82 Parkinsonlu birey ve 68 sağlıklı bireyin serum D vitamini düzeylerine bakılmıştır. Çalışma sonuçlarına göre Parkinsonlu bireylerde ciddi anlamda düşük D vitamini düzeyleri saptanmıştır. (Abou-Raya ve diğ., 2009). 
Tablo 1. Parkinsonlu bireylerde D vitamini alım miktarı ve düzeyiyle ilgili yapılan çalışmalar

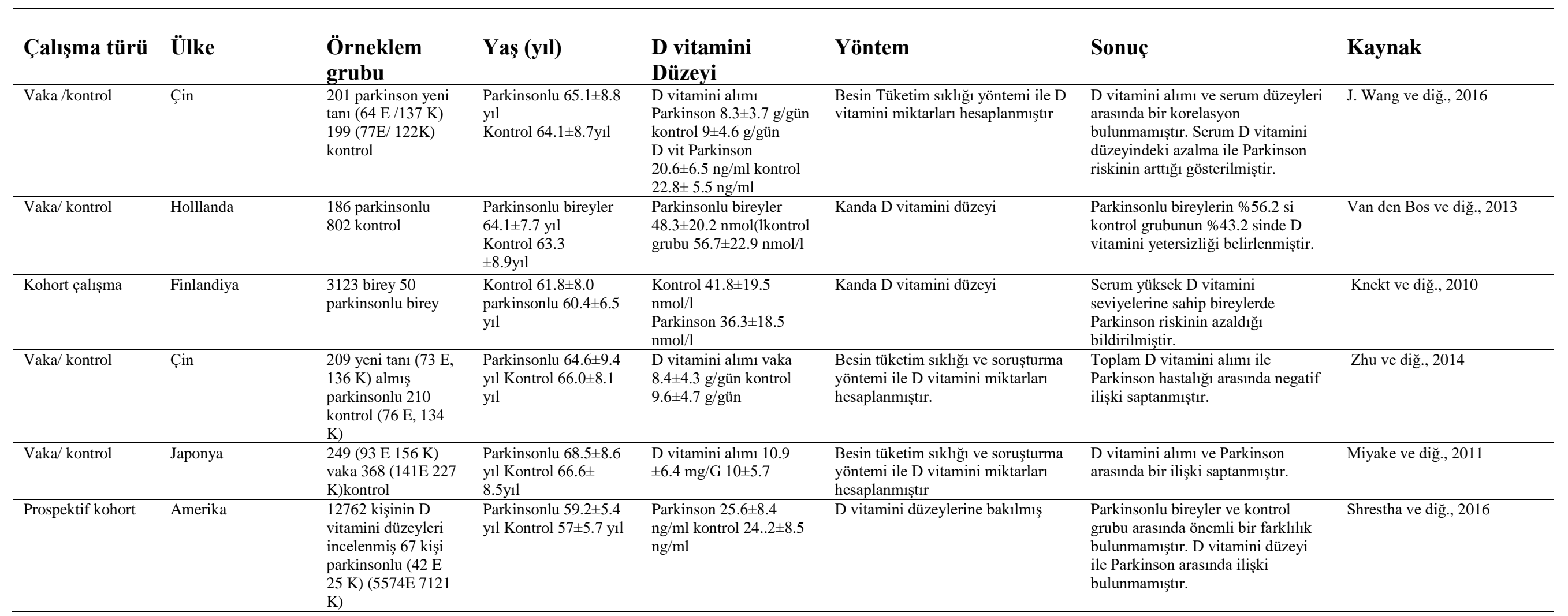




\section{Sonuç ve Öneriler}

D vitamini alımı, diyet ve güneş 1şığı ile belirlendiğinden Parkinson hastalığında değiştirilebilir çevresel bir faktör olarak düşünülmektedir. Yapılan çalışmalarda D vitamini eksikliği ve yetersizliğinin Parkinsonlu bireylerde diğer gruplara kıyasla daha yüksek oranda olduğu belirlenmiştir. Hastalık, motor ve motor dışı semptomlardan dolayı kişilerin gündelik yaşam kalitesini önemli ölçüde olumsuz yönde etkilemektedir. Ancak yapılan çalışmalardaki örneklem büyüklüğü, D vitamini suplementasyonuna yönelik çalışmaların az olması, D vitamini ölçüm zamanlarındaki farklılıklar ve hastaların Parkinson tedavisinde kullandıkları ilaçlar ve beslenme durumları D vitamini düzeylerini etkileyebilmektedir. Özellikle Parkinson hastalığı prevalansının yaşlı bireylerde daha yüksek olması ve bu popülasyonun D vitamini yetersizliği ve eksikliği riski taşımasından dolayı düzenli serum D vitamini takipleri yapılmalı. Bireysel olarak yetersizlik varsa eğer destek verilebilir. D vitamini parkinsondan koruyucu özelliğe sahip olmasına rağmen bu yöndeki kanıtlar sınırlıdır. Hastalığın patolojisinde vitaminin rolü ve önlenmesine yönelik mekanizmaların anlaşılması için deneysel ve gözlem çalışmalarına ihtiyaç duyulmaktadır. 


\section{Kaynakça}

Abou-Raya, S., Helmii, M., \& Abou-Raya, A. (2009). Bone and mineral metabolism in older adults with Parkinson's disease. Age and Ageing, 38(6), 675-680.

Buell, J. S., \& Dawson-Hughes, B. (2008). Vitamin D and neurocognitive dysfunction: preventing "D" ecline? Molecular Aspects of Medicine, 29(6), 415-422.

Butler, M. W., Burt, A., Edwards, T. L., Zuchner, S., Scott, W. K., Martin, E. R., Wang, L. (2011). Vitamin D receptor gene as a candidate gene for Parkinson disease. Annals of Human Genetics, 75(2), 201-210.

Combs, B. L., \& Cox, A. G. (2017). Update on the treatment of Parkinson's disease psychosis: role of pimavanserin. Neuropsychiatric Disease and Treatment, 13, 737.

de Jongh, R. T., van Schoor, N. M., \& Lips, P. (2017). Changes in vitamin D endocrinology during aging in adults. Molecular and Cellular Endocrinology,453, 144-150

Ding, H., Dhima, K., Lockhart, K. C., Locascio, J. J., Hoesing, A. N., Duong, K., Wills, A.-M. (2013). Unrecognized vitamin D3 deficiency is common in Parkinson disease Harvard Biomarker Study. Neurology, 81(17), 1531-1537.

Dringen, R., Gutterer, J. M., \& Hirrlinger, J. (2000). Glutathione metabolism in brain. The FEBS Journal, 267(16), 4912-4916.

Ellis, J. M., \& Fell, M. J. (2017). Current approaches to the treatment of Parkinson's Disease. Bioorganic \& Medicinal Chemistry Letters.

Erro, R., Brigo, F., Tamburin, S., Zamboni, M., Antonini, A., \& Tinazzi, M. (2017). Nutritional habits, risk, and progression of Parkinson disease. Journal of Neurology, 1-12.

Evatt, M. L., DeLong, M. R., Khazai, N., Rosen, A., Triche, S., \& Tangpricha, V. (2008). Prevalence of vitamin D insufficiency in patients with Parkinson disease and Alzheimer disease. Archives of Neurology, 65(10), 1348-1352.

Eyles, D. W., Smith, S., Kinobe, R., Hewison, M., \& McGrath, J. J. (2005). Distribution of the vitamin D receptor and 1 $\alpha$-hydroxylase in human brain. Journal of Chemical Neuroanatomy, 29(1), 21-30.

Garcion, E., Nataf, S., Berod, A., Darcy, F., \& Brachet, P. (1997). 1, 25-Dihydroxyvitamin D 3 inhibits the expression of inducible nitric oxide synthase in rat central nervous system during experimental allergic encephalomyelitis. Molecular Brain Research, 45(2), 255-267.

Garcion, E., Sindji, L., Leblondel, G., Brachet, P., \& Darcy, F. (1999). 1, 25-Dihydroxyvitamin D3 regulates the synthesis of $\gamma$-glutamyl transpeptidase and glutathione levels in rat primary astrocytes. Journal of Neurochemistry, 73(2), 859-866.

Garcion, E., Sindji, L., Montero-Menei, C., Andre, C., Brachet, P., \& Darcy, F. (1998). Expression of inducible nitric oxide synthase during rat brain inflammation: Regulation by 1 , 25-dihydroxyvitamin D3. Glia, 22(3), 282-294.

Garcion, E., Wion-Barbot, N., Montero-Menei, C. N., Berger, F., \& Wion, D. (2002). New clues about vitamin D functions in the nervous system. Trends in Endocrinology and Metabolism, 13(3), 100-105.

Han, X., Xue, L., Li, Y., Chen, B., \& Xie, A. (2012). Vitamin D receptor gene polymorphism and its association with Parkinson's disease in Chinese Han population. Neuroscience Letters, 525(1), 29-33.

Henchcliffe, C., \& Beal, M. F. (2008). Mitochondrial biology and oxidative stress in Parkinson disease pathogenesis. Nature clinical practice Neurology, 4(11), 600-609.

Herrmann, M., Widmann, T., Colaianni, G., Colucci, S., Zallone, A., \& Herrmann, W. (2005). Increased osteoclast activity in the presence of increased homocysteine concentrations. Clinical Chemistry, 51(12), 2348-2353.

Kang, S. Y., Park, S., Oh, E., Park, J., Youn, J., Kim, J. S., . . Jang, W. (2016). Vitamin D receptor polymorphisms and Parkinson's disease in a Korean population: Revisited. Neuroscience Letters, 628, 230-235.

Kenborg, L., Lassen, C. F., Ritz, B., Schernhammer, E. S., Hansen, J., Gatto, N. M., \& Olsen, J. H. (2010). Outdoor work and risk for Parkinson9s disease: a population-based case-control study. Occupational and Environmental Medicine, oem. 2010.057448.

Knekt, P., Kilkkinen, A., Rissanen, H., Marniemi, J., Sääksjärvi, K., \& Heliövaara, M. (2010). Serum vitamin D and the risk of Parkinson disease. Archives of Neurology, 67(7), 808-811. 
Kosakai, A., Ito, D., Nihei, Y., Yamashita, S., Okada, Y., Takahashi, K., \& Suzuki, N. (2011). Degeneration of mesencephalic dopaminergic neurons in klotho mouse related to vitamin D exposure. Brain Research, 1382, 109-117.

Lin, A. M., Fan, S., Yang, D., Hsu, L., \& Yang, C. (2003). Zinc-induced apoptosis in substantia nigra of rat brain: neuroprotection by vitamin D3. Free Radical Biology and Medicine, 34(11), 1416-1425.

Lv, Z., Qi, H., Wang, L., Fan, X., Han, F., Wang, H., \& Bi, S. (2014). Vitamin D status and Parkinson's disease: a systematic review and meta-analysis. Neurological Sciences, 35(11), 1723-1730. doi:10.1007/s10072-014-1821-6

Miyake, Y., Tanaka, K., Fukushima, W., Sasaki, S., Kiyohara, C., Tsuboi, Y., Kawamura, N. (2011). Lack of association of dairy food, calcium, and vitamin D intake with the risk of Parkinson's disease: a case-control study in Japan. Parkinsonism \& Related Disorders, 17(2), 112-116.

Ozturk, E. A., Gundogdu, I., Tonuk, B., Kocer, B. G., Tombak, Y., Comoglu, S., \& Cakci, A. (2016). Bone mass and vitamin D levels in Parkinson's disease: is there any difference between genders? Journal of physical therapy science, 28(8), 2204-2209.

Peterson, A. L. (2014). A review of vitamin D and Parkinson's disease. Maturitas, 78(1), 40-44.

Pringsheim, T., Jette, N., Frolkis, A., \& Steeves, T. D. (2014). The prevalence of Parkinson's disease: A systematic review and meta-analysis. Movement Disorders, 29(13), 1583-1590.

Puchacz, E., Stumpf, W. E., Stachowiak, E. K., \& Stachowiak, M. K. (1996). Vitamin D increases expression of the tyrosine hydroxylase gene in adrenal medullary cells. Molecular Brain Research, 36(1), 193-196.

Rimmelzwaan, L. M., van Schoor, N. M., Lips, P., Berendse, H. W., \& Eekhoff, E. M. (2016). Systematic review of the relationship between vitamin D and Parkinson's disease. Journal of Parkinson's Disease, 6(1), 29-37.

Rizek, P., Niraj Kumar MD, D., \& Jog, M. S. (2016). An update on the diagnosis and treatment of Parkinson disease. Canadian Medical Association. Journal, 188(16), 1157.

Sato, Y., Iwamoto, J., \& Honda, Y. (2011). Vitamin D deficiency-induced vertebral fractures may cause stooped posture in Parkinson disease. American Journal of Physical Medicine and Rehabilitation, 90(4), 281-286.

Sato, Y., Kikuyama, M., \& Oizumi, K. (1997). High prevalence of vitamin D deficiency and reduced bone mass in Parkinson's disease. Neurology, 49(5), 1273-1278.

Shen, L., \& Ji, H.-F. (2015). Associations between vitamin d status, supplementation, outdoor work and risk of parkinson's disease: A meta-analysis assessment. Nutrients, 7(6), 4817-4827.

Shinpo, K., Kikuchi, S., Sasaki, H., Moriwaka, F., \& Tashiro, K. (2000). Effect of 1, 25-dihydroxyvitamin D3 on cultured mesencephalic dopaminergic neurons to the combined toxicity caused by L-buthionine sulfoximine and 1-methyl-4-phenylpyridine. Journal of Neuroscience Research, 62(3), 374-382.

Shrestha, S., Lutsey, P. L., Alonso, A., Huang, X., Mosley, T. H., \& Chen, H. (2016). Serum 25-hydroxyvitamin D concentrations in Mid-adulthood and Parkinson's disease risk. Movement Disorders, 31(7), 972-978.

Suzuki, M., Yoshioka, M., Hashimoto, M., Murakami, M., Noya, M., Takahashi, D., \& Urashima, M. (2013). Randomized, double-blind, placebo-controlled trial of vitamin D supplementation in Parkinson disease. The American journal of clinical nutrition, 97(5), 1004-1013.

Török, R., Török, N., Szalardy, L., Plangar, I., Szolnoki, Z., Somogyvari, F., Klivenyi, P. (2013). Association of vitamin D receptor gene polymorphisms and Parkinson's disease in Hungarians. Neuroscience Letters, 551, 70-74.

Van den Bos, F., Speelman, A., Van Nimwegen, M., van der Schouw, Y., Backx, F., Bloem, B., .. . Verhaar, H. (2013). Bone mineral density and vitamin D status in Parkinson's disease patients. Journal of Neurology, 260(3), 754-760.

Wang, J., Yang, D., Yu, Y., Shao, G., \& Wang, Q. (2016). Vitamin D and sunlight exposure in newlydiagnosed Parkinson's disease. Nutrients, 8(3), 142.

Wang, L., Evatt, M. L., Maldonado, L. G., Perry, W. R., Ritchie, J. C., Beecham, G. W., Vance, J. M. (2015). Vitamin D from different sources is inversely associated with Parkinson disease. Movement Disorders, 30(4), 560-566. 
Zhang, Z.-T., He, Y.-C., Ma, X.-J., Li, D.-Y., \& Lu, G.-C. (2014). Association between vitamin D receptor gene polymorphisms and susceptibility to Parkinson's disease: a meta-analysis. Neuroscience Letters, 578, 122-127.

Zhu, D., Liu, G.-y., Lv, Z., Wen, S.-r., Bi, S., \& Wang, W.-z. (2014). Inverse associations of outdoor activity and vitamin D intake with the risk of Parkinson's disease. Journal of Zhejiang University. Science. B, 15(10), 923. 